\title{
Current Research: Spiro and Caddoan Connections on the Northern Frontier of Southwest Missouri
}

Jack H. Ray

Center for Archaeological Research, Missouri State University

Follow this and additional works at: https://scholarworks.sfasu.edu/ita

Part of the American Material Culture Commons, Archaeological Anthropology Commons, Environmental Studies Commons, Other American Studies Commons, Other Arts and Humanities Commons, Other History of Art, Architecture, and Archaeology Commons, and the United States History Commons

Tell us how this article helped you.

This Article is brought to you for free and open access by the Center for Regional Heritage Research at SFA ScholarWorks. It has been accepted for inclusion in Index of Texas Archaeology: Open Access Gray Literature from the Lone Star State by an authorized editor of SFA ScholarWorks. For more information, please contact cdsscholarworks@sfasu.edu. 


\section{Current Research: Spiro and Caddoan Connections on the Northern Frontier of Southwest Missouri}

\section{Creative Commons License}

\section{(c) (1) (8)}

This work is licensed under a Creative Commons Attribution-NonCommercial 4.0 International License 


\title{
Current Research: \\ Spiro and Caddoan Connections on the Northern Frontier of Southwest Missouri
}

\author{
Jack H. Ray \\ Center for Archaeological Research, Missouri State University
}

Excavations during the construction of Table

Rock Lake in the late 1950s resulted in a proposition that there was a colonization of peoples into the upper White River drainage from Caddoan areas to the southwest (Chapman 1980; Chapman et al. 1960). This colonization, which resulted in the formulation of the Loftin phase, is widely accepted today (O'Brien and Wood 1998; Perttula 1983, 1989; Sabo and Early 1990). Later, James Brown (1984) exposed the myth that the southwestern Ozarks was a cultural enclave that lagged behind Mississippian developments in other parts of the Trans-Mississippi South.

Recent discoveries and reanalysis of artifacts from 19 sites located across much of Southwest Missouri indicate that a substantial presence and influence of Caddoan peoples extended far beyond the upper White River valley. This area, referred to as the Northern Frontier of the Caddoan realm (Ray 2018), extends from the lower James River valley on the south to the Osage River on the north.

Multiple lines of evidence suggest this portion of the western Ozarks was within the Caddoan orbit and sphere of influence. This evidence includes: (1) perforated and unperforated pulley-shaped stone earspools, (2) engraved Spiro ceramics and bonetempered pottery, (3) a newly recognized Caddoan mound in the headwaters of the James River, (4) a human effigy pipe, (5) exotic marine shells, (6) a petroglyph exhibiting Caddoan iconography, and (7) selected Caddoan projectile points. This evidence from 19 sites is detailed by Ray (2018) and is only summarized here. Seven sites with Caddoan connections are located in the upper James River basin on the south of the Ozarks Divide, whereas 12 sites are located in the upper Sac River basin and the middle Osage River basin on the north side of the Ozarks Divide (Figure 1).

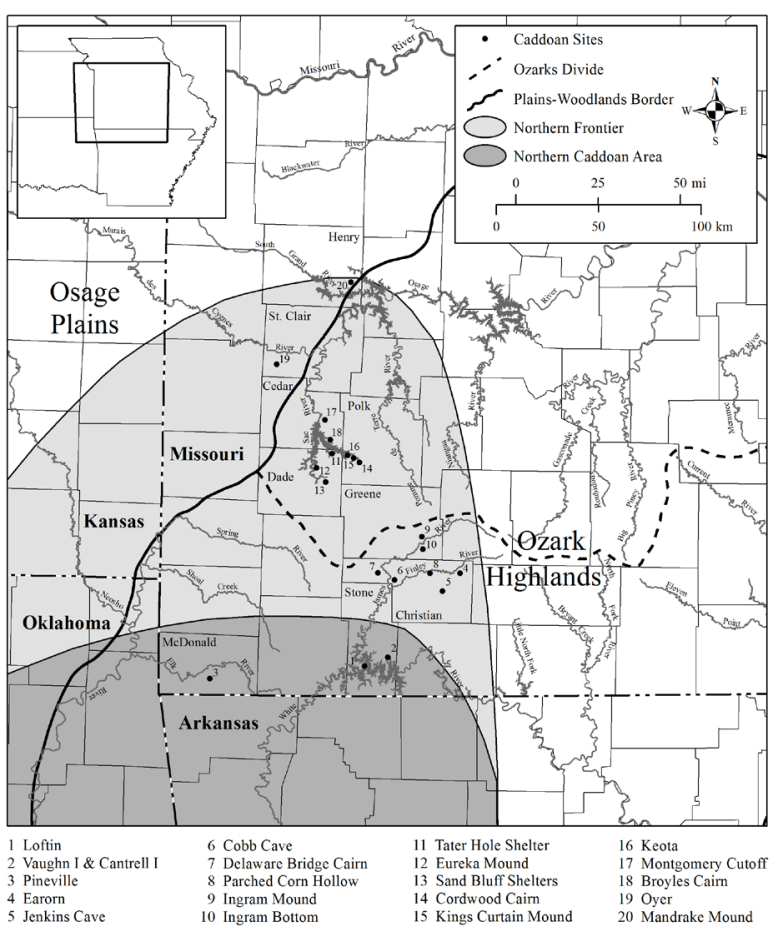

Figure 1. Location of the Northern Frontier area and Caddoan sites discussed in text.

Perhaps the most convincing evidence is the presence of several pulley-shaped earspools and earspools with copper residue at multiple sites in the Northern Frontier. Earspools, especially those of the pulley-shaped type, are firmly associated with early Caddoan sites as well as the Spiro Ceremonial Center in the Arkansas River valley of eastern Oklahoma (Bell 1984:234-235; Brown 1996:563-567; Hamilton 1952:55-56, 203). Two previously unreported highstatus pulley-shaped earspools came to light in 2009. Both were found at an open-air habitation site called Earorn in the upper Finley River basin in Christian County. One is a decorated and formerly coppercovered unperforated pulley-shaped stone earspool 

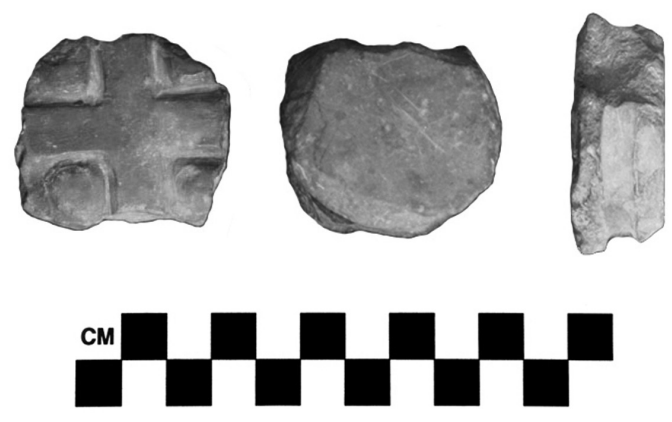

Figure 2. Exterior face, interior face, and edge view of decorated, unperforated, pulley-shaped earspool from the Earorn site.

(Figure 2), the only earspool of this type ever reported from Missouri. It is very similar, if not identical, to the decorated unperforated earspool type (cross quadrating field of 12 nodes) that was found in a prestigious burial grave lot in the Craig Mound at Spiro (Brown 1996:Figure 2.120f). The second earspool is a fragment of a large undecorated perforated pulley-shaped type.

Other undecorated perforated pulley-shaped earspools manufactured from local dolostone have been recovered from two habitation sites and one burial tumulus. These are Jenkins Cave in Christian County, Sand Bluff E Shelter in Dade County, and Cordwood Cairn in Polk County. Suspected trade of exotic Caddoan artifacts into the northern Ozarks, perhaps in association with seasonal hunting parties, has long been recognized. However, high-value luxury artifacts of personal adornment from residential sites suggests a more sustained presence of Caddoan-affiliated peoples (including those of elite status) in the Northern Frontier.

Several Caddoan pottery sherds have been found in Southwest Missouri. An intact Spiro Engraved water bottle from the Eureka Mound has generally been thought to represent trade (Wood and Pangborn 1968). Another Spiro Engraved sherd was recovered from Broyles Cairn. However, other Spiro Engraved pottery sherds have been found at habitation sites, including three from Sand Bluff C Shelter and one from Tater Hole Shelter. In addition, certain utilitarian wares tempered with crushed bone or in combination with grit and/or grog can be associated with the Caddoan ceramic tradition and appear to indicate domestic use unassociated with trade. Fourteen sherds tempered with grit and bone were recovered from Sand Bluff C Shelter in Dade County (McMillan 1966:33-34), whereas Ingram Mound, Cobb Cave, and Tater Hole Shelter have yielded smaller quantities of bone-, grit-and-bone-, and/ or grit-grog-and-bone-tempered pottery. Other sites in Southwest Missouri may contain pottery with bone as a temper, but they are as yet unknown because the temper was unrecognized or misidentified. Additionally, undecorated Caddoan plain pottery tempered with grog and grit-and-grog that exhibits frequent wiping marks on the interior and/or exterior surfaces (e.g., Williams Plain) have been found at Ingram Mound and Parched Corn Hollow Shelter.

Earthen mounds, whether for the burial of the elite or other ceremonial purposes, were an integral part of early Caddoan (e.g., Harlan phase and Loftin phase) societies in the southwestern Ozarks. They were located in strategic locations in bottomland contexts and spaced at relatively regular intervals (Kay et al. 1989; Perttula 1983; Wyckoff 1980). Incomplete excavations and inadequate analyses of the materials recovered from Ingram Mound in Greene County resulted in this bottomland mound not being affiliated with other Caddoan mounds in the southwestern Ozarks. However, a reexamination of the pottery and other artifacts from Ingram Mound and adjacent areas indicates that it should now be recognized as yet another Caddoan mound (with a possible attendant nearby hamlet) located near the headwaters of the James River more than 70 $\mathrm{km}$ north of the Loftin site. Although inconclusive, this small mound appears to represent a burial tumulus of an individual (or individuals) of high status.

An unusual human effigy sandstone pipe was found at a habitation site on the lower Sac River in Cedar County (Ray and Montgomery 2011). The pipe (called the Montgomery pipe) depicts an anatomically correct nude female in a kneeling position with legs folded beneath her, abdomen resting on her thighs, and hands on her knees (Figure 3). The Montgomery pipe shares few attributes with known Caddoan human effigy pipes. Attributes on certain pipes from the lower Mississippi River valley appear to conform most closely to those on the Montgomery pipe (Coe 1976:Figures 39-40; Ray and Montgomery 2011:168-173). If the Montgomery pipe is not a local Caddoan-manufactured pipe, the find location of this pipe on the western periphery of the northern Ozarks and its affinity with 


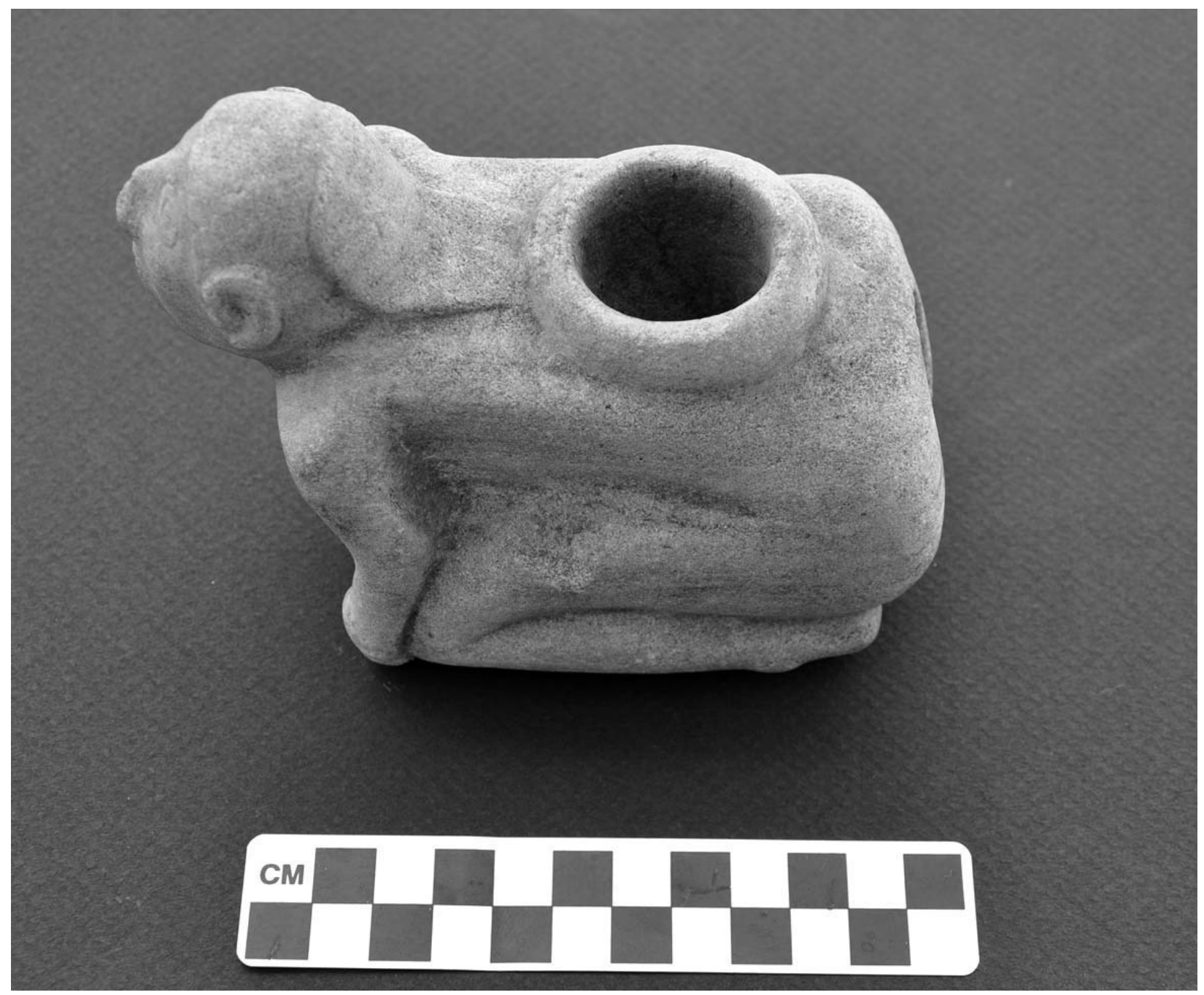

Figure 3. Side view of the Montgomery pipe from the Montgomery Cutoff site (after Ray and Montgomery 2011:Figure 1).

attributes of pipes from the Mississippi River valley suggest that this high-status object probably arrived in Southwest Missouri through the extensive trade network that the Arkansas Valley Caddoans had established with inhabitants of the Sac River valley and the lower Mississippi River valley.

The presence of marine shell beads, especially conch and Marginella, indicate a trade connection with the Gulf Coast. Marine shell beads have been found in five mortuary mounds in the Northern Frontier area that appear to have Caddoan components. It is important to note, however, that marine shell artifacts are not restricted to mounds with Caddoan components. They have been found in many mounds that appear to have been constructed by groups indigenous to the northern Ozarks (Wood 1967:Table 1; Wood and Brock
1984:Table 1). Whether the exotic shell artifacts in these mounds were obtained directly by indigenous groups or by trade with Caddoan groups to the south, some of which may have been periodic residents in the Northern Frontier, remains equivocal.

A petroglyph found at the Oyer site at the north end of the Northern Frontier in St. Clair County appears to be affiliated with Arkansas Valley Caddoan iconography. This petroglyph is framed by a slightly asymmetrical square with small squared loops at each corner (Figure 4). Two vertical oblong figures are located within the square frame. The left figure appears to represent a woodpecker, a bird not uncommon in Caddoan iconography. Phillips and Brown (1975:153) referred to a square with looped corners as a "looped square" and tentatively assigned the looped square 


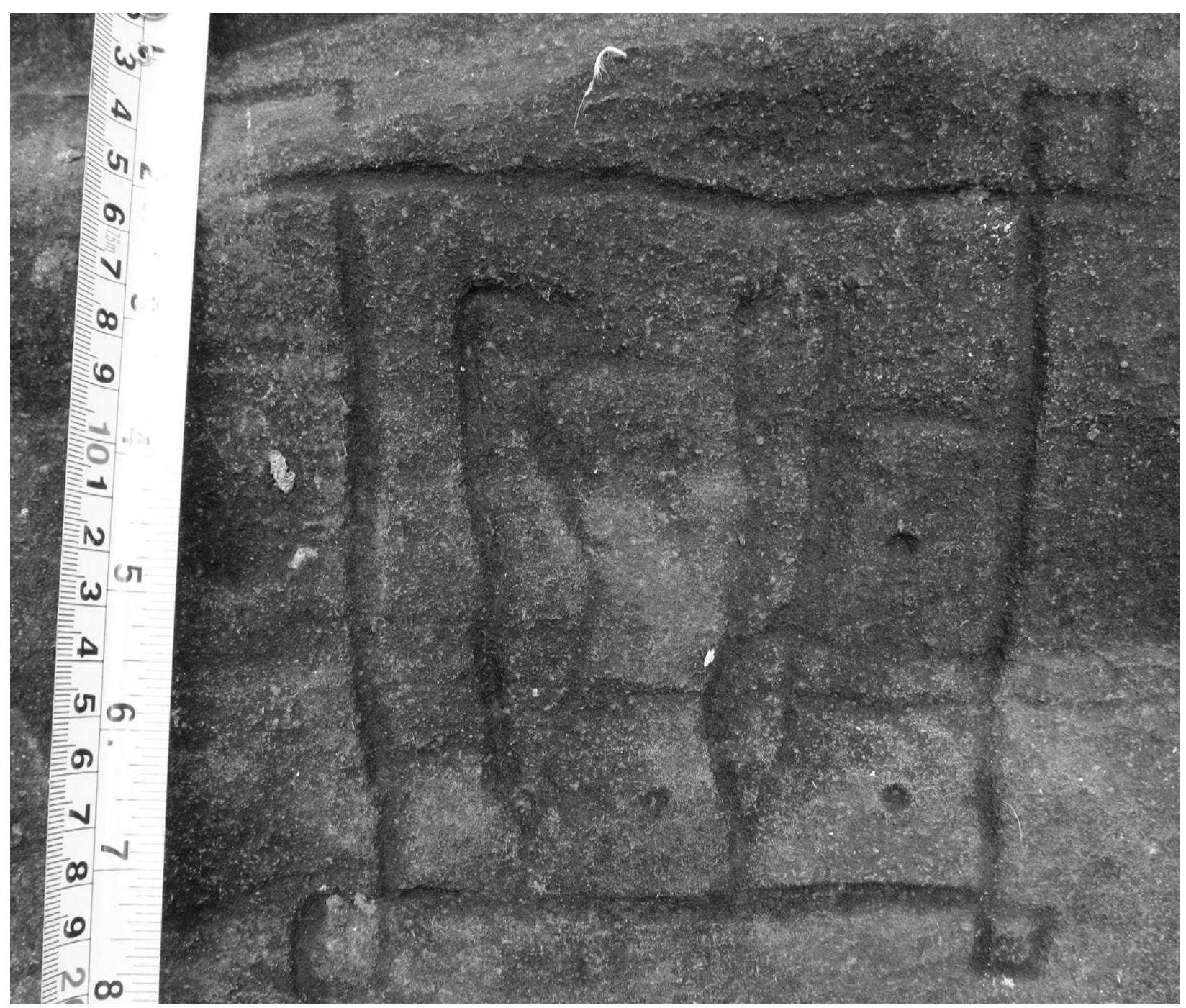

Figure 4. Looped-square petroglypyh from the Oyer site (courtesy of Doug Porter).

design to the Craig A style of Caddoan iconography. The same design appears prominently on a stone earspool (Hamilton 1952:Plate 81) and one shell cup engraving from the Craig Mound at Spiro (Phillips and Brown 1979:Plate 186f). Unlike a high-prestige marine shell artifact that might have been traded, a petroglyph is an abstraction of an idea directly represented by the individual who inscribed it. Given the location of the Oyer site on the western flank of the Ozarks, this petroglyph could represent an ideological connection between those living in the Northern Frontier and those living in the Arkansas River valley to the south.

Projectile points are generally less diagnostic of specific components than ceramic artifacts. The most common arrow point type in the Ozarks is Scallorn, whereas certain other small arrow points, such as Alba,
Keota, and Bonham, are atypical and occur rarely in Southwest Missouri. These three arrow point types are found primarily in the southern Caddo area. Atypical arrow points found at Sand Bluff B Shelter in Dade County include one contracting-stemmed Alba point and two square-stemmed Bonham arrow points (McMillan 1966:12 and Figure 3b-c). A side-notched Keota arrow point found at a site in Polk County was made from Arkansas novaculite, located in the Ouachita Mountains of west central Arkansas more than $275 \mathrm{~km}$ to the south. Other side-notched arrow points with straight (Reed) to concave bases with squared (Haskell) and rounded (Morris) ears appear to be restricted to the southwestern Ozarks and Caddoan-affiliated sites (Bell 1984:233-234; Brown 1996). The common occurrence of these sidenotched arrow point types in Northeast Oklahoma, 
Northwest Arkansas, and Southwest Missouri, and their rare occurrence in Central and Southeast Missouri, appears to indicate a general range of Caddoan influence and presence in the southwestern Ozarks. Stemmed and corner-notched dart points/knives, such as Montgomery and Cupp, also are concentrated primarily in the Caddoan area of the southwestern Ozarks (Ray 2016:24, 102).

Mid-twentieth century investigations in the Sac, Pomme de Terre, and Osage river valleys in Southwest Missouri resulted in a long-standing view that local Late Woodland populations remained relatively isolated and were not greatly influenced by Caddoan groups located not far to the south (Vehik 1978:48; Wood 1961:118, 1967:125-126). With the exception of a handful of engraved ceramic sherds recovered from Sand Bluff C Shelter, most recognized Caddoan artifacts were viewed as luxury goods from burial mounds that were obtained as a result of trade, not by the movements of Caddoan peoples into the area.

New analyses and recent discoveries from Southwest Missouri indicate a greater presence of Caddoan or Caddoan-affiliated peoples in the Northern Frontier area than previously recognized and requires a reassessment of the presence of Caddoan peoples in the western portion of the northern Ozarks. This growing body of evidence suggests that a substantial presence and sphere of influence of Caddoan peoples may have extended far beyond the upper White River valley into the Northern Frontier. Radiocarbon ages from two apparent Caddoan sites in this Northern Frontier (Jenkins Cave and Ingram Bottom), and circumstantial evidence from several other sites, suggest that a surge of Caddoan influence and possible quasi-political control occurred over much of Southwest Missouri ca. A.D. 1100-1350 as local late prehistoric inhabitants in the area became more firmly identified and integrated with the Caddoan lifestyle that flourished in the Arkansas River valley. This shift from a Late Woodland to Caddoan lifestyle appears to have begun in the upper White River valley to the south approximately 150 years earlier: between A.D. 900-1000 (Bell 1984:221; Brown 1984:30). The Caddoan presence and influence appears to have waned after widespread population displacement and the collapse of most regional ceremonial centers in the southwestern Ozarks around A.D. 1350-1400 and was ultimately replaced by the late prehistoric Neosho tradition.

We know of a Caddoan presence at Loftin, Vaughn I, Cantwell I, Pineville Mound, and other sites located in the southern tier of Missouri counties that border Arkansas (Brown 1984:22). We must now seriously consider that Caddoan peoples had a greater presence and influence farther north in the Northern Frontier area than previously acknowledged. Bell (1984:239-240) hinted at this possibility and suggested that the Harlan phase population expanded not only into new portions of the Ozarks but also expanded to the north as far as the Missouri River valley and the eastern portion of the Central Plains.

\section{References Cited}

Bell, Robert E.

1984 Arkansas Valley Caddoan: The Harlan Phase. In Prehistory of Oklahoma, edited by Robert E. Bell, pp. 221-240. Academic Press, Orlando.

Brown, James A.

1984 Prehistoric Southern Ozark Marginality: A Myth Exposed. Special Publication No. 6. Missouri Archaeological Society, Columbia.

1996 The Spiro Ceremonial Center: The Archaeology of Arkansas Valley Caddoan Culture in Eastern Oklahoma. Memoir No. 29. 2 Vols. Museum of Anthropology, University of Michigan, Ann Arbor.

Chapman, Carl H.

1980 The Archaeology of Missouri, II. University of Missouri Press, Columbia.

Chapman, Carl H., Richard A. Marshall, Robert T. Bray, W. Raymond Wood, Dale R. Henning, Rolland E. Pangborn, Charles M. Keller, and Bonnie B. Keller

1960 Archaeological Investigations in the Table Rock Reservoir Area, Missouri. Archaeological Research Division. University of Missouri, Columbia. Submitted to the National Park Service, Lincoln. 
Coe, Ralph T.

1976 Sacred Circles: Two Thousand Years of North American Indian Art. Lund Humphries, London.

Hamilton, Henry W.

1952 The Spiro Mound. The Missouri Archaeologist 14:23-276.

Kay, Marvin, George Sabo, III, and Ralph Merletti 1989 Late Prehistoric Settlement Patterning: A View from Three Caddoan Civic-Ceremonial Centers in Northwest Arkansas. In Contributions to Spiro Archeology: Mound Excavations and Regional Perspectives, edited by J. Daniel Rogers, Don G. Wyckoff, and Dennis A. Peterson, pp. 129-157. Studies in Oklahoma's Past No. 16. Oklahoma Archeological Survey, Norman.

McMillan, R. Bruce

1966 Archaeological Investigations in the Stockton Reservoir Area, Southwestern Missouri: 1962-1964, Part II. Missouri Archaeological Research Division, Department of Sociology and Anthropology, University of Missouri, Columbia.

O'Brien, Michael J. and W. Raymond Wood

1998 The Prehistory of Missouri. University of Missouri Press, Columbia.

Perttula, Timothy K.

1983 The Loftin Site and Phase in Western Ozark Prehistory. The Missouri Archaeologist 44:40-62.

1989 The Late Prehistoric Period in the Western Ozarks of Southwest Missouri. In Contributions to Spiro Archaeology: Mound Centers and Regional Perspectives, edited by J. Daniel Rogers, Don G. Wyckoff, and Dennis A. Peterson, pp. 117-127. Studies in Oklahoma's Past No. 16. Oklahoma Archeological Survey, Norman.

Phillips, Philip, and James A. Brown

1975 Pre-Columbian Shell Engravings from the Craig Mound at Spiro, Oklahoma, Vol. 1. Peabody Museum Press, Harvard University, Cambridge.
1979 Pre-Columbian Shell Engravings from the Craig Mound at Spiro, Oklahoma, Vol. 4. Peabody Museum Press, Harvard University, Cambridge.

Ray, Jack H.

2016 Projectile Points in Missouri and Portions of Adjacent States. Special Publication No. 10. The Missouri Archaeological Society, Springfield.

2018 Ear Spools, Ceramics, and Burial Mounds from Southwest Missouri: Caddoan and Spiro Connections on the Northern Frontier. Southeastern Archaeology 37(1):58-81.

Ray, Jack H., and A. Clark Montgomery

2011 A Unique Human Effigy Pipe from Cedar County, Missouri. The Missouri Archaeologist 72:161175.

Sabo, George, III and Ann M. Early

1990 Prehistoric Culture History. In Human Adaptation in the Ozark and Ouachita Mountains, by George Sabo III, Ann M. Early, Jerome C. Rose, Barbara A. Burnett, Louis Vogele, Jr., and James P. Harcourt, pp. 34-120. Research Series No. 31. Arkansas Archeological Survey, Fayetteville, Arkansas.

Vehik, Rain

1978 An Analysis of Cultural Variability During the Late Woodland Period in the Ozark Highland of Southwest Missouri. Ph.D. dissertation, Department of Anthropology, University of Missouri, Columbia.

Wood, W. Raymond

1961 The Pomme de Terre Reservoir in Western Missouri Prehistory. The Missouri Archaeologist 23:1-132.

1967 The Fristoe Burial Complex of Southwestern Missouri. The Missouri Archaeologist 29 (whole volume). 
Wood, W. Raymond, and Sharon L. Brock

1984 The Bolivar Burial Complex of Southwestern Missouri. The Missouri Archaeologist 45 (whole volume).

Wood, W. Raymond, and Rolland E. Pangborn

1968 The Eureka and Comstock Mounds, Southwestern Missouri. Plains Anthropologist 13(39):1-17.
Wyckoff, Don G.

1980 Caddoan Adaptive Strategies in the Arkansas Basin, Eastern Oklahoma. Ph.D. dissertation, Department of Anthropology, Washington State University, Pullman. 